\title{
Opportunistic protozoa in HIV seropositive cases and best stool concentration technique for detection
}

\author{
P Sreenivasulu Reddy ${ }^{*}$, P Madhurima, P Vasundhara Devi \\ From First International Science Symposium on HIV and Infectious Diseases (HIV SCIENCE 2012) \\ Chennai, India. 20-22 January 2012
}

\section{Introduction}

Parasitic gastrointestinal diseases increase morbidity and mortality in HIV patients. This study is aimed at the occurrence of Cryptosporidium, Isospora, Cyclospora and Microsporidium in the stool samples of HIV positive cases since the diarrhea is the second most common presentation of HIV positive cases who requires hospitalization.

\section{Materials and methods}

Stool specimen from HIV infected patients $(n=100)$ were included. Each time specimens were divided into two portions of which one was plain and second part mixed with $10 \%$ buffered formalin saline in 3:1 ratio. Blood samples were collected for lymphocyte counts. Samples were processed and compared with Formal-Ether sedimentation and Sheather's sugar floatation technique for the detection of oocysts.

\section{Results}

Isospora belli was predominant opportunistic protozoa detected. Cryptosporidium oocysts were found in 2 cases of acute diarrhea and one case with chronic diarrhea. No Cyclospora and Microspora were detected. Sheather's sugar floatation technique is found better in concentrating the oocysts of Isospora and Cryptosporidium. Along the oocysts, 2 cases of Ancylostoma duodenale, one case of each Giradia lamblia and Strongyloides stercoralis were detected.

\section{Conclusion}

While testing for detection of protozoan parasites from HIV cases, it needs to collect multiple stool samples if feasible. Sheather's sugar floatation technique is superior to Formal-Ether sedimentation to detect the oocysts of Cryptosporidium and Isospora belli. Absolute lymphocyte count is probably good when used as a marker for CD4 count assessment where the facilities are not available for $\mathrm{CD} 4$ count testing.

Published: 4 May 2012

doi:10.1186/1471-2334-12-S1-P2

Cite this article as: Reddy et al:: Opportunistic protozoa in HIV

seropositive cases and best stool concentration technique for detection. BMC Infectious Diseases 2012 12(Suppl 1):P2.

* Correspondence: sr.palukuru@gmail.com

Department of Microbiology, Narayana Medical College, Nellore, Andhra Pradesh, India

Submit your next manuscript to BioMed Central and take full advantage of:

- Convenient online submission

- Thorough peer review

- No space constraints or color figure charges

- Immediate publication on acceptance

- Inclusion in PubMed, CAS, Scopus and Google Scholar

- Research which is freely available for redistribution

Submit your manuscript at www.biomedcentral.com/submit
C Biomed Central 